\title{
Changes In The Composition Of Migration For States: 1955-60 To 1965-70 \#
}

\author{
WiLLIAM J. SEROW*
}

\section{Introduction}

If future levels of fertility in the United States remain at something like those of the present, the future population of this country will become more or less stationary. While this may suggest a host of economic and social problems [15], it also suggests a lessening of concern with the question of overpopulation for the nation as a whole. It is more likely that concern with such problems will be concentrated at the local level, since population movement and population redistribution will continue. The purpose of the present paper is to systematically examine patterns of migration at the state level for the 1955-60 and 1965-70 quinquennia. The data employed in this paper come from printed reports stemming from both the 1960 and 1970 censuses of population, [17-20] which deal with population mobility for the five year period immediately preceding the census.

The Commission on Population Growth and the American Future has commented on the "... virtually endless list of programs which have unintended consequences for the territorial arrangement of the population." [5, p. 59] Later, the Commission recommends that: "The Federal Government develop a set of national population distribution guidelines to serve as a framework for regional, state and local plans and development. [5, p. 120] Certainly, there is considerable evidence that current patterns of residential preference and residential location are not in agreement. [6]

If a national redistribution policy is to be enacted, it is important to develop policies appropriate to deal with the problem. The policy tools which would prospectively affect inmigration and outmigration might be quite different. For example, in an area with persistent net outmigration, one might first desire to stem this tide, then perhaps at a later time develop policies designed to increase inmigration to the area. In order to accomplish this goal, it is necessary to have knowledge of recent trends in rates of in and out migration for localities. The aim of this paper is to supply and analyze some of the basic data at the state level, and point to some of the determinants of changes in these trends. It is hoped that further research will examine data for smaller areas (SMSAs, county groups, state economic areas, etc.) and examine more thoroughly the determinants of in and out migration, rather than merely concentrating on net migration.

\# An earlier version of this paper was presented at the 1975 meeting of the American Statistical Association. This material is used with the permission of the Association.

*Research Director, Population Studies Center, Tayloe Murphy Institute, University of Virginia. 
Analysis of in- and outmigration, unless done with some care, can obscure more than it reveals. Consider, for example, Morrison's case of Albuquerque, New Mexico, which between 1960 and 1970 received a total of 22 'net migrants.' As Morrison notes: “. . . this net figure masks the comings and goings of about 14 or 15 people per hundred working-age residents every year. In fact, each year of the decade, some 44,000 residents were last year's in-migrants and 44,000 were next year's out-migrants." [12, p. 11] Renshaw [13] is another case in point on the importance of using gross rather than net migration data.

Changing patterns of population movements arise for many reasons. There have been a plethora of studies seeking to determine the causes and concomitants of migration, based on both streams of migration. Many of these stem from the work of Blanco [2], and Lowry. [11] Another large body of literature deals only with net migration. [7] The theoretical development of this area stems mainly from Lee [9] and Sjaastad. [16]

\section{The Data}

In the analysis and discussion that follow, the data will be utilized exactly as they appear in the printed reports. It is important to remember though, that in both quinquennia, the data are based on samples (25 percent in 1960 and 15 percent in 1970). Hence, the data are subject to some sampling error. In those cases, for example, where net migration is approximately zero, the number which would be obtained in a complete enumeration would vary somewhat in either direction. Rhode Island, for example, had about 873,000 persons aged five and over in 1970. Between 1965 and 1970, the state received some 93,200 inmigrants and lost about 92,400 outmigrants. The standard error is such that the actual numbers would not vary by more than 1100-1200 from the sample data. Hence, actual net migration for the state might vary from $+3200(94,400-91,200)$ to -1600 (92,000-93,600).

Table 1 shows the sign of net migration, and the change, in percentage points, in rates of in, out, net, and gross migration for all states and divisions for 1955-60 and 1965-70. ${ }^{1}$ Thus, Maine showed net outmigration for both periods. However, the rate of inmigration increased by 0.9 percentage points over the quinquennia, while the rate of outmigration increased by 0.6 percentage points. Hence, the rate of net migration increased slightly (from -2.8 percent to -2.4 percent), while the gross migration rate increased by 1.5 percentage points.

Net migration measures the contribution of migration to population change in the area in question. Between 1955-60 and 1965-70, the rate of net migration increased in 29 states and declined in 22 . Furthermore, the rate of net migration rose in six of nine census divisions. The rate of net migration to an area can increase in a variety of ways: both in- and outmigration rates can rise, but the former to a greater extent; both rates can deccline, but the former to a lesser extent; or, the inmigration rate can go up while the outmigration rate goes down. For declines in the rate of net migration, the converse of each of these statements would hold. Table 2 classifies states and divisions in terms of the percentage point change in the net migration rate as a function of the change in the in- and 
Table 1. Direction of Net Migration and Percentage Point Change in Migration Rates, States and Divisions: 1955-60 to $1965-70$

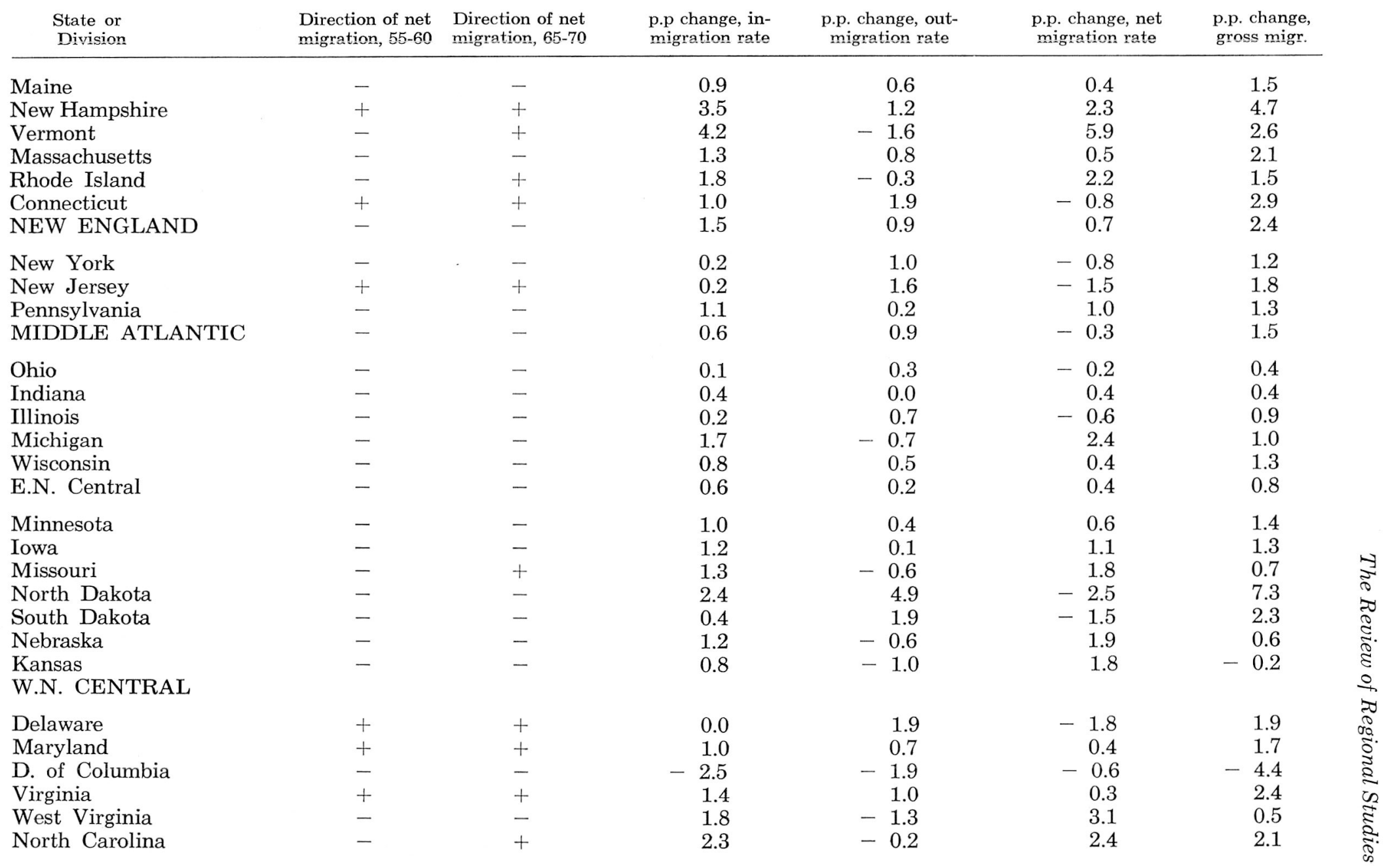


Table 1. Direction of Net Migration and Percentage Point Change in Migration Rates, States and Divisions: $1955-60$ to $1965-70$ (continued)

\begin{tabular}{|c|c|c|c|c|c|c|}
\hline $\begin{array}{l}\text { State or } \\
\text { Division }\end{array}$ & $\begin{array}{l}\text { Direction of net } \\
\text { migration, } 55-60\end{array}$ & $\begin{array}{l}\text { Direction of net } \\
\text { migration, } 65-70\end{array}$ & $\begin{array}{l}\text { p.p change, in- } \\
\text { migration rate }\end{array}$ & $\begin{array}{l}\text { p.p. change, out- } \\
\text { migration rate }\end{array}$ & $\begin{array}{l}\text { p.p. change, net } \\
\text { migration rate }\end{array}$ & $\begin{array}{l}\text { p.p. change, } \\
\text { gross migr. }\end{array}$ \\
\hline South Carolina & - & + & 2.5 & -0.3 & 2.7 & 2.2 \\
\hline Georgia & - & + & 2.9 & -0.2 & 3.1 & 2.7 \\
\hline Florida & + & + & -6.6 & 1.9 & -8.4 & -4.7 \\
\hline SOUTH ATLANTIC & + & + & 0.6 & 0.3 & 0.3 & 0.9 \\
\hline Kentucky & - & - & 1.3 & -1.0 & 2.3 & 0.3 \\
\hline Tennessee & - & + & 1.5 & -1.1 & 2.7 & 0.4 \\
\hline Alabama & - & - & 0.6 & 1.2 & -0.6 & 1.8 \\
\hline Mississippi & - & - & 1.4 & 0.1 & 1.2 & 1.5 \\
\hline E.S. CENTRAL & - & - & 1.2 & -0.2 & 1.4 & 1.0 \\
\hline Arkansas & - & - & 1.2 & -2.2 & 3.4 & -1.0 \\
\hline Louisiana & - & - & 0.4 & 1.5 & -1.0 & 1.9 \\
\hline Oklahoma & - & + & 2.0 & -1.7 & 3.7 & 0.3 \\
\hline Texas & - & + & 1.2 & -0.7 & 1.7 & 0.5 \\
\hline W.S. CENTRAL & - & + & 1.1 & -0.6 & 1.7 & 0.5 \\
\hline Montana & - & - & 0.5 & 3.2 & -2.7 & 3.7 \\
\hline Idaho & - & - & 1.2 & 1.4 & -0.2 & 2.6 \\
\hline Wyoming & - & - & -1.8 & 2.7 & -4.6 & 0.9 \\
\hline Colorado & + & + & 0.9 & 0.6 & 0.3 & 1.5 \\
\hline New Mexico & + & - & -7.0 & 4.7 & -11.7 & -3.3 \\
\hline Arizona & + & + & -4.9 & 2.6 & -7.4 & -2.3 \\
\hline Utah & + & - & 0.5 & 2.5 & -2.0 & 3.0 \\
\hline Nevada & + & + & -3.8 & -0.6 & -3.2 & -4.4 \\
\hline MOUNTAIN & + & + & -1.2 & 2.1 & -3.3 & 0.9 \\
\hline Washington & + & + & 3.1 & -1.9 & 5.0 & 1.2 \\
\hline Oregon & - & + & 2.1 & -1.3 & 3.4 & 0.8 \\
\hline California & + & + & -4.0 & 2.1 & -6.1 & -1.9 \\
\hline Alaska & + & + & -3.0 & -0.1 & -2.8 & -3.1 \\
\hline Hawaii & + & - & 2.5 & 4.9 & -2.4 & 7.4 \\
\hline PACIFIC & + & + & -2.4 & 1.4 & -3.7 & -1.0 \\
\hline
\end{tabular}

Sources: 1960 Census, Mobility for States and State Economic Areas, Tables 25, 26, 27 1970 Census, Mobility for States and the Nation, Tables 56, 57, 58 
Table 2. Patterns of Change in Migration Rates, States and Divisions: $1955-60$ to $1965-70$

\begin{tabular}{|c|c|c|c|c|c|c|}
\hline & $\begin{array}{l}\text { Increase IMR } \\
\text { Increase OMR } \\
\text { Increase NMR }\end{array}$ & $\begin{array}{l}\text { Increase IMR } \\
\text { Increase OMR } \\
\text { Decrease INIRR }\end{array}$ & $\begin{array}{l}\text { Increase IMR } \\
\text { Decrease OMR } \\
\text { Increase NIIIR }\end{array}$ & $\begin{array}{l}\text { Decrease IMR } \\
\text { Increase OMR } \\
\text { Decrease INMIR }\end{array}$ & $\begin{array}{l}\text { Decrease IMR } \\
\text { Decrease OMR } \\
\text { Decrease INIMR }\end{array}$ & Other \\
\hline & $\begin{array}{l}\text { Maine } \\
\text { New Hampshire } \\
\text { Massachusetts } \\
\text { Pennsylavia } \\
\text { Wisconsin } \\
\text { Minnesota } \\
\text { Iowa } \\
\text { Maryland } \\
\text { Virginia } \\
\text { Mississippi } \\
\text { Colorado }\end{array}$ & $\begin{array}{l}\text { Connecticut } \\
\text { New York } \\
\text { New Jersey } \\
\text { Ohio } \\
\text { Illinois } \\
\text { North Dakota } \\
\text { South Dakota } \\
\text { Alabama } \\
\text { Louisiana } \\
\text { Montana } \\
\text { Idaho } \\
\text { Utah } \\
\text { Hawaii }\end{array}$ & $\begin{array}{l}\text { Vermont } \\
\text { Rhode Island } \\
\text { Michigan } \\
\text { Missouri } \\
\text { Nebraska } \\
\text { Kansas } \\
\text { West Virginia } \\
\text { North Carolina } \\
\text { South Carolina } \\
\text { Georgia } \\
\text { Kentucky } \\
\text { Tennessee } \\
\text { Arkansas } \\
\text { Oklahoma } \\
\text { Texas } \\
\text { Washington } \\
\text { Oregon }\end{array}$ & $\begin{array}{l}\text { Florida } \\
\text { Wyoming } \\
\text { New Mexico } \\
\text { Arizona } \\
\text { California }\end{array}$ & $\begin{array}{l}\text { District of Col. } \\
\text { Nevada } \\
\text { Alaska }\end{array}$ & $\begin{array}{l}\text { Indiana* } \\
\text { Delaware** }\end{array}$ \\
\hline & $\begin{array}{l}\text { NEW ENGLAND } \\
\text { E.N. CENTRAL } \\
\text { SOUTH } \\
\quad \text { ATLANTIC }\end{array}$ & $\begin{array}{l}\text { MIDDLE } \\
\text { ATLANTIC }\end{array}$ & $\begin{array}{l}\text { E.S. CENTRAL } \\
\text { W.S. CENTRAL }\end{array}$ & $\begin{array}{l}\text { MOUNTAIN } \\
\text { PACIFIC }\end{array}$ & & $\begin{array}{l}\text { W.N. } \\
\text { CENTRAL }\end{array}$ \\
\hline & $\begin{array}{l}11 \text { states } \\
3 \text { divisions }\end{array}$ & $\begin{array}{l}13 \text { states } \\
1 \text { division }\end{array}$ & $\begin{array}{l}17 \text { states } \\
2 \text { divisions }\end{array}$ & $\begin{array}{l}5 \text { states } \\
2 \text { divisions }\end{array}$ & 3 states & $\begin{array}{l}2 \text { states } \\
1 \text { division }\end{array}$ \\
\hline \multicolumn{7}{|l|}{ Mean } \\
\hline $\begin{array}{l}\text { IMR } \\
\text { OMR } \\
\text { NMR }\end{array}$ & $\begin{array}{l}1.32 \\
0.56 \\
0.77\end{array}$ & $\begin{array}{r}0.78 \\
2.08 \\
-1.29\end{array}$ & $\begin{array}{r}1.94 \\
-0.98 \\
2.91\end{array}$ & $\begin{array}{r}-4.86 \\
2.80 \\
-7.64\end{array}$ & $\begin{array}{l}-3.10 \\
-0.87 \\
-2.22\end{array}$ & \\
\hline
\end{tabular}

Source: same as Table 1 
outmigration rates. Three patterns are particularly important: a) increase in both in- and outmigration rates, increase in net migration; b) increase in both rates, decrease in net migration; and c) increase in inmigration, decrease in outmigration, increase in net migration. These accounted for 11, 13, and 17 states respectively -41 of a total of 51 . These patterns were also descriptive of six divisions.

The pattern of all three migration rates increasing shows some signs of regional concentration - half the New England states, three states in the upper midwest, and the two states surrounding the nation's capital were of this type. Generally, states in this group had net outmigration during both periods, with the exceptions of New Hampshire, Colorado, Maryland, and Virginia.

Those states with increases in both in- and outmigration, but declines in the net migration rate included five industrial states in the northeast (including those which comprise the entire New York metropolitan area), both Dakotas, two gulf coast states, three Rocky Mountain states, and Hawaii. Again, most of these states had net outmigration for both periods except for Connecticut, New Jersey, Utah, and Hawaii.

The pattern of declining net migration rates both through declines in inmigration rates and increases in outmigration rates contains four states with extremely high rates of in- and net migration for 1955-60. Net migration remained high in Florida, Arizona, and to a lesser extent, California, but the data do suggest somewhat of an abatement of what might be termed a migration boom of the late 1950 's. New Mexico is somewhat of a puzzle showing the largest-by-far-percentage point decline in the rate of net migration. Between 1955 and 1960, New Mexico had a net migration rate of 5.3 percent, a level surpassed by only six states. During the period between 1965 and 1970, New Mexico's rate of net migration was -6.4 percent, a level exceeded only in the Dakotas, the District of Columbia, and (marginally) Wyoming.

The single most prevalent pattern was that of an increase in the net migration rate through increasing inmigration rates and decreasing outmigration rates. This pattern prevailed in most of the southeastern and south central portions of the nation, as well as in parts of New England and the Pacific Northwest. All of those states which experienced net outmigration for 1955-60 and net inmigration for 1965-70 (Vermont, Rhode Island, Missouri, the Carolinas, Georgia, Tennessee, Oklahoma, Texas, and Oregon) were included in this group. Since states in this group were the only cases where movements in both in- and outmigration rates acted to increase the net migration rate, it is not surprising that the average increase in the rate of net migration was highest for states in this group. However, the average increase in the inmigration rate was also highest for states in this category.

Morrison has noted that rapidly growing cities have high rates of both inand outmigration. For states, the situation seems to be that high rates of gross migration are associated with high rates of net migration, regardless of the sign of the latter. For the 1965-70 quinquennium, the simple correlation coefficient between the volume of gross migration and the absolute number of "net migrants" was .74 $(\mathrm{t}=7.8) ; \mathrm{r}$ for gross and net migration, considering the sign of the latter 
was only .23. If the concepts of gross and net migration are tied to the concept of migration efficiency, ${ }^{2}$ there is a strong relationship between the net migration rate (absolute value) and the rate of efficiency $(\mathrm{r}=.71, \mathrm{t}=7.0)$, but a rather weak one between gross migration and migration efficiency $(\mathrm{r}=.14, \mathrm{t}=0.97)$. In other words, states with highly mobile populations tend to have relatively large differences between inmigration and outmigration, and, hence, high net migration (in either direction). Furthermore, the higher the rate of net migration, the more efficient the migration.

\section{Changes in the Demographic Components of Migration}

In many cases, there might be more interest in the reasons for changes in migration rates, rather than merely the changes themselves. This section deals with changes in the rates of migration as a function of changes in rates by age and race. ${ }^{3}$ Percentage point changes in the three migration rates, by race, are shown in Table 3. In the interest of preserving space, the discussion of these data will be limited to those states with a change in the direction of migration or a decline in migration between the 1955-60 and 1965-70 quinquennia.

Those states which went from net outmigration during the latter portion of the 1950's to net inmigration ten years later generally showed increases in the rate of net migration for both races. The bulk of these states were in the southeast or southwest. The typical pattern was an increase in net inmigration rates among whites, and a decrease in the rate of net outmigration among nonwhites.

Those states which went from net inmigration to net outmigration all experienced declines in the rate of net migration for whites. In the cases of New Mexico and Utah, the direction of white migration changed as well. However, in Utah and Hawaii, the rate of nonwhite migration increased, although clearly not enough to offset the decline among whites.

States which showed a decline in the rate of net migration between periods fell into three general categories: states with little or no population growth and low rates of migration (New York, Ohio, Illinois, Alabama, Louisiana), states with little or no population growth, but high rates of migration (the Dakotas, the District of Columbia, Montana, Idaho, Wyoming, Utah), and states with high rates of population growth during the 1950's, and generally high rates of migration, but which slowed down somewhat during the later quinquennium. These included Connecticut, New Jersey, Delaware, Florida, Arizona, Nevada, California, Alaska, New Mexico, and Hawaii. In all cases but Utah and Hawaii, these states experienced declines in both white and nonwhite net inmigration between the 1955-60 and 1965-70 periods. The latter two states, along with Maryland, were the only instances of increased net inmigration for nonwhites accompanied by decreases in the white rate. Increases in the rate for both races were found in four midwestern states (Indiana, Michigan, Minnesota, Kansas), six southeastern states (Virginia, West Virginia, the Carolinas, Georgia, Kentucky), two southwestern states (Texas and Oklahoma), and the two states of the Pacific northwest. 

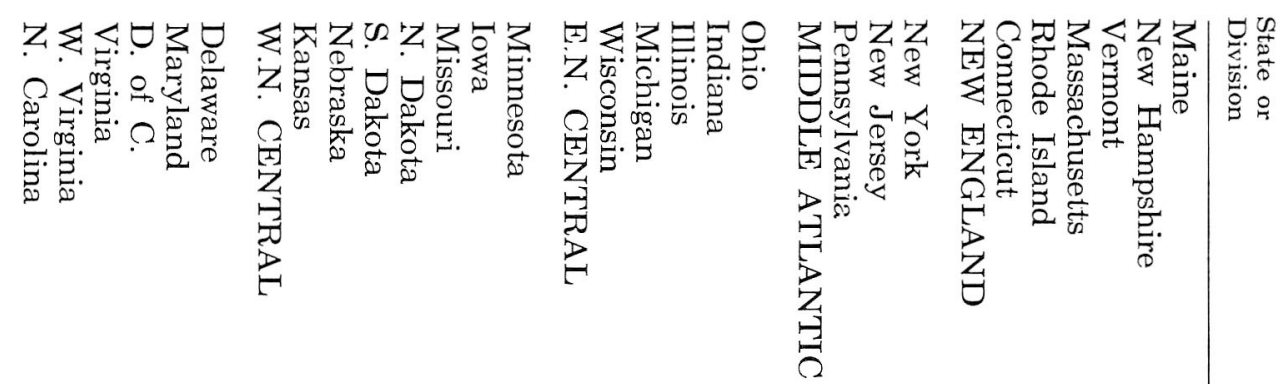

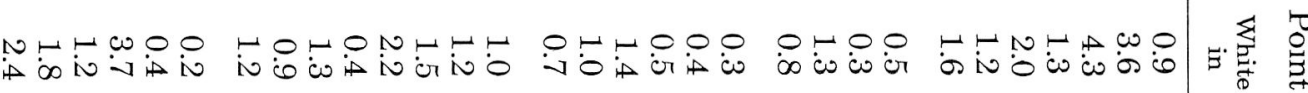

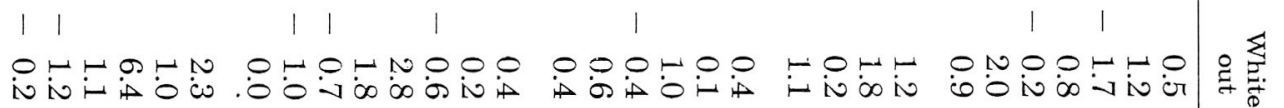

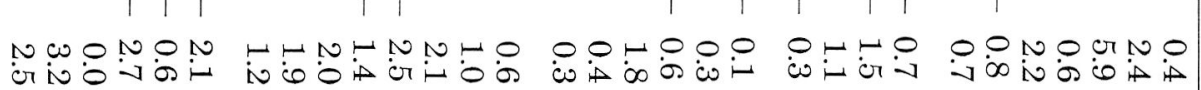


Table 3. Percentage Point Changes in Migration Rates, by Race, States and Divisions: 1955-60 to 1965-70 (Continued)

\begin{tabular}{|c|c|c|c|c|c|c|}
\hline $\begin{array}{l}\text { State or } \\
\text { Division }\end{array}$ & $\begin{array}{c}\text { White } \\
\text { in }\end{array}$ & $\begin{array}{c}\text { White } \\
\text { out }\end{array}$ & $\begin{array}{l}\text { White } \\
\text { net }\end{array}$ & $\begin{array}{l}\text { Nonwhite } \\
\text { in }\end{array}$ & $\begin{array}{c}\text { Nonwhite } \\
\text { out }\end{array}$ & $\begin{array}{l}\text { Nonwhite } \\
\text { net }\end{array}$ \\
\hline S Carolina & 2.3 & 0.3 & 2.1 & 1.8 & -1.5 & 3.3 \\
\hline Georgia & 3.3 & 0.0 & 3.1 & 1.5 & -0.9 & 2.4 \\
\hline Florida & -7.5 & 1.9 & -9.4 & -3.3 & 1.6 & -4.8 \\
\hline S. ATLANTIC & 0.3 & 0.3 & 0.1 & 1.1 & 0.4 & 0.8 \\
\hline Kentucky & 1.4 & -1.1 & 2.5 & 0.5 & 0.1 & 0.5 \\
\hline Tennessee & 1.7 & -1.5 & 3.2 & 0.5 & 0.8 & -0.4 \\
\hline Alabama & 0.5 & 0.8 & -0.2 & 0.4 & 2.4 & -2.1 \\
\hline Mississippi & 1.0 & -0.5 & 1.5 & 0.8 & 1.3 & -0.4 \\
\hline E.S. CENTRAL & 1.2 & -0.7 & 1.9 & 0.7 & 1.4 & -0.7 \\
\hline Arkansas & 1.2 & -2.8 & 4.1 & 0.2 & 0.4 & -0.1 \\
\hline Louisiana & 0.5 & 1.5 & -1.0 & 0.2 & 1.6 & -1.4 \\
\hline Oklahoma & 2.2 & -1.6 & 3.8 & 2.0 & -1.2 & 3.2 \\
\hline Texas & 1.1 & -0.7 & 1.9 & 1.4 & 0.2 & 1.2 \\
\hline W.S. CENTRAL & 1.2 & -0.8 & 1.9 & 1.0 & 0.5 & 0.4 \\
\hline Montana & 0.4 & 3.1 & -2.6 & 4.5 & 9.1 & -4.6 \\
\hline Idaho & 1.2 & 1.4 & -0.2 & 4.7 & 6.2 & -1.5 \\
\hline Wyoming & -1.8 & 2.9 & -4.7 & 2.8 & 4.4 & -1.6 \\
\hline Colorado & 1.0 & 0.7 & 0.4 & 0.0 & 1.2 & -1.3 \\
\hline New Mexico & -7.4 & 5.0 & -12.4 & -0.3 & 4.7 & -5.0 \\
\hline Arizona & -5.4 & 2.5 & -7.9 & -0.2 & 3.1 & -3.4 \\
\hline Utah & 0.4 & 2.7 & -2.3 & 7.6 & -0.9 & 8.5 \\
\hline Nevada & -3.3 & -0.5 & -2.8 & -7.7 & 1.5 & -9.1 \\
\hline MOUNTAIN & -1.2 & 2.1 & -3.8 & 1.1 & 3.7 & -2.6 \\
\hline Washington & 3.3 & -1.9 & 5.2 & 2.0 & 1.6 & 0.3 \\
\hline Oregon & 2.2 & -1.2 & 3.4 & 3.9 & 1.1 & 2.9 \\
\hline California & -3.9 & 2.3 & -6.2 & -4.1 & 1.2 & -5.3 \\
\hline Alaska & -3.0 & -1.2 & -1.9 & 0.6 & 6.6 & -6.0 \\
\hline Hawaii & -4.1 & 6.4 & -10.6 & 1.6 & 0.7 & 0.9 \\
\hline PACIFIC & -2.2 & 1.4 & -3.8 & -1.8 & 1.0 & -2.8 \\
\hline
\end{tabular}


Another demographic variable which is important in the analysis of changing migration patterns is age. Individuals are most prone toward migratory behavior at certain stages of their life-the most obvious example being in the late teens and early twenties when persons most often leave home to take their first job, get married, further education, enter military service, and so on.

A great deal of migration of young persons is reflected in college and military migration. ${ }^{4}$ Military migration is of perhaps greater interest for two reasons: first, there is more of it; second, it is the result of a policy decision (not related to migration) to a greater and more systematic extent than is college migration.

During the 1955-60 quinquennium, the number of transfers of residence between states among college students totalled about 97,000; the number of such moves among military personnel was nearly $378,000 .{ }^{5}$ The number of states gaining population appreciably through college was fairly small: Massachusetts and Indiana (12,900 each), Colorado (8,100), Utah $(6,600)$, and California $(17,400)$. Similarly, large losses of population due to net outmigration among college students were limited to these states: New York (24,400), New Jersey $(20,000)$, and Illinois $(15,700)$. In relative terms, migration of college students diminished considerably net outmigration in Massachusetts and Indiana, and added appreciably to net inmigration in Colorado and Utah. The latter, in fact, would have experienced net outmigration had it not been for college migration. Although college migration was large in the other states mentioned, only in New Jersey did it have an important effect on the total migration pattern, lowering somewhat the level of net inmigration.

Military migration had a much more widespread effect. Several states, including Rhode Island, Maryland, Virginia, the Carolinas, Georgia, Florida, Texas, California, Alaska, and Hawaii had a net gain of at least 10,000 military personnel, with California gaining more than 110,000 . Similarly, the number of states losing population in large amounts through military migration was quite large: New York, Pennsylvania, Ohio, Indiana, Illinois, Michigan, Wisconsin, Minnesota, Iowa, West Virginia, and Oregon.

The combined effects of military and college migration were extremely important in many cases. In some states such as Virginia, Louisiana, Utah, Alaska, and Hawaii the effects were such as to change the sign of net migration. Except for Utah, the effects were primarily from the military, and except for Louisiana, the effect was to create net inmigration. In several states, these factors accounted for more than one third of net migration (Ohio, Illinois, Michigan, Wisconsin, Minnesota, Idaho, Wyoming, and Washington). In other states, military and college trends blunted the overall level of net outmigration (Massachusetts, Rhode Island, Missouri, Kansas, the Carolinas, Georgia, Kentucky, and Texas) or bolstered the level of net inmigration (New Hampshire, Maryland, Colorado, New Mexico, Arizona, and California). Only in the cases of New Jersey and Connecticut were levels of net inmigration lowered by net outmigration of college students and military personnel.

The volume of both college and military migration increased substantially during the 1965-70 period. Total college movements rose to more than 218,000, 
while military movements increased to almost 660,000. The overall pattern remained much the same as that of the earlier quinquennium, but there were some changes. College net migration increased in northern New England, Michigan, Wisconsin, Missouri, much of the southeast and southwest, and on the Pacific coast. Outmigration of college students increased most notably in the Middle Atlantic and East North Central divisions; in fact, these were the only divisions with net college outmigration, and the only ones where the level of net migration declined between quinquennia. The largest increases occurred in the South Atlantic, West South Central (essentially Texas), and Pacific divisions.

The reason for the increase in military movement was primarily the increase in military activity in Southeast Asia. A great deal of this increase was felt in the South, which, as a whole, experienced a net military inmigration of more than 210,000 . The West, particularly on the coast, gained more than 150,000 persons, with more than 100,000 of these in California. Virginia, with a net gain of nearly 75,000 , was also a large beneficiary of the war, in demographic terms. Besides Virginia, there were several other states which experienced net inmigration during the 1965-70 period directly as a result of military migration: Rhode Island, both Carolinas, and Alaska.

Between 1955-60 and 1965-70, there were increases in net migration ${ }^{6}$ in New England, the East and West North and South Central divisions, and the South Atlantic states. In New England and the West North Central states, increases in college migration played a relatively small role; these were more than offset by sizeable increases in net military outmigration. In the East North Central division, net migration increased despite decreases in both college and military net migration. The three divisions which comprise the South all saw college and military net migration increase along with the total. The increase in these components was responsible for 40 percent of the total increase in the South Atlantic division, and 9 and 12 percent in the East and West South Central divisions, respectively.

The three divisions with declines in net migration over the decade were the Middle Atlantic, Mountain, and Pacific. The first of these saw substantial decline in both college and military migration-these accounted for more than 70 percent of the total decline. In the Mountain states, total migration declined despite modest increases in both college and military net migration. The substantial decline in net inmigration to the Pacific states was little affected by the small increase in college migration or the even smaller decrease in military migration (see Table 4).

Migration of older persons is a subject which has received increasing scrutiny in recent years. $[1 ; 8]$ Some portion of this is no doubt represented by return migration. [3; 4; 10] Between 1955-60 and 1965-70, several portions of the country began to become alternative (to Florida, Arizona, and California) destinations for older persons. These include northern New England, the southeast, the southwest, and the northwest. As a rule, increases in migration of older persons to these areas paralleled overall increases in migration. States which have historically been important destinations for elderly migrants continued to attract 
Table 4. Changes in the Volume of Total, College, and Military Net Migration, States and Divisions: 1955-60 to 1965-70

\begin{tabular}{|c|c|c|c|c|c|c|c|}
\hline $\begin{array}{l}\text { State or } \\
\text { Division }\end{array}$ & Total & College & Military & $\begin{array}{l}\text { State } \\
\text { Division }\end{array}$ & Total & College & Military \\
\hline Maine & 2,159 & $-\quad 1,719$ & $-\quad 5,357$ & S. Carolina & 57,287 & $-\quad 1,522$ & 721 \\
\hline $\mathrm{N} \in \mathrm{W}$ Hampshire & 16,626 & 2,472 & $-\quad 3,631$ & Georgia & 116,351 & 6,778 & 4,662 \\
\hline Vermont & 21,833 & 1,291 & $-\quad 350$ & Florida & $-203,291$ & 9,667 & 4,492 \\
\hline Massachusetts & 21,592 & 6,003 & $-\quad 9,678$ & S. ATLANTIC & 178,392 & 19,826 & 51,584 \\
\hline Rhode Island & 16,302 & 632 & 1,996 & Kentucky & 59,587 & 3,931 & 1,400 \\
\hline Connecticut & $-14,216$ & $-\quad 5,437$ & $-\quad 3,074$ & Tennessee & 83,285 & 7,595 & $\begin{array}{r}1,400 \\
-\quad 2,160\end{array}$ \\
\hline NEW ENGLAND & 64,296 & 1,978 & $-20,094$ & Alabama & $-20,972$ & $-\quad 1,703$ & 6,571 \\
\hline New York & $-165,091$ & $-31,261$ & $-10,455$ & Missiscippi & 22,039 & $-\quad 1,873$ & 715 \\
\hline New Jersey & $-71,326$ & $-31,924$ & $-12,166$ & E.S. CENTRAL & 143,939 & 7,950 & 5,096 \\
\hline Pennsylvania & 89,255 & $-17,873$ & 616 & Arkansas & 53,240 & 396 & $-\quad 1,144$ \\
\hline MIDDLE & & & & Louisiana & $-32,189$ & $-\quad 2,269$ & 12,111 \\
\hline ATLANTIC & $-147,162$ & $-81,058$ & $-23,237$ & Oklahoma & 76,687 & 3,089 & 957 \\
\hline Ohio & $-21,402$ & $-\quad 5,076$ & $-11,868$ & Texas & 166,897 & 12,544 & 6,725 \\
\hline Indiana & 9,387 & $-\quad 4,025$ & $-\quad 5,843$ & W.S. CENTRAI & L 264,635 & 13,760 & 18,649 \\
\hline Illinois & - 72,221 & $-13,152$ & 6,231 & Montana & $-17,539$ & $-\quad 2,244$ & $-\quad 1,837$ \\
\hline Michigan & 162,564 & 5,109 & $-\quad 3,884$ & Idaho & $-\quad 1,622$ & 978 & 244 \\
\hline Wisconsin & 10,264 & 5,907 & $-6,070$ & Wyoming & $-13,686$ & $-\quad 1,066$ & 1,425 \\
\hline E.N. CENTRAL & 88,592 & $-11,337$ & $-21,434$ & Colorado & 22,552 & 8,754 & 12,196 \\
\hline Minnesota & 15,817 & $-1,004$ & $-\quad 4,521$ & New Mexico & $-98,934$ & $-\quad 1,713$ & $-\quad 6,265$ \\
\hline Iowa & 23,316 & $-\quad 3,871$ & $-\quad 3,775$ & Arizona & $-52,225$ & 6,274 & 2,306 \\
\hline Missouri & 69,512 & 6,505 & $-\quad 6,736$ & Utah & $-17,296$ & 7,156 & 842 \\
\hline N. Dakota & $-13,880$ & $-\quad 1,840$ & 2,607 & Nevada & 471 & $-\quad 1,082$ & 4,379 \\
\hline S. Dakota & $-\quad 8,880$ & 338 & 226 & MOUNTAIN & $-178,278$ & 15,051 & 11,606 \\
\hline Nebraska & 20,298 & 2,184 & $-\quad 4,064$ & Washington & 154,948 & 7,083 & 9,096 \\
\hline Kansas & 32,463 & 1,475 & 4,854 & Oregon & 61,411 & 5,296 & $-\quad 3,362$ \\
\hline W.N. CENTRAL & 138,646 & 3,111 & $-11,861$ & California & $-752,221$ & 20,753 & $-\quad 8,525$ \\
\hline Delaware & $-\quad 4,874$ & 538 & $-\quad 1,654$ & Alaska & $-3,176$ & 734 & $-\quad 1,115$ \\
\hline Maryland & 35,705 & 585 & 1,449 & Hawaii & $-14,031$ & $-\quad 1,679$ & $-\quad 2,667$ \\
\hline D. of C. & 210 & 724 & 513 & PACIFIC & $-553,060$ & 30,719 & $-\quad 6,573$ \\
\hline Virginia & 22,752 & $-\quad 4,789$ & 24,899 & & & & \\
\hline W. Virginia & 56,709 & 4,038 & 1,843 & & & & \\
\hline N. Carolina & 97,963 & 5,255 & 16,101 & & & & \\
\hline
\end{tabular}

Source: 1960 Census, Mobility for States and State Economic Areas, Tables 20 and 22 1970 Census, Mobility for States and the Nation, Tables 48 and 52 
large numbers, but at somewhat lower rates. Again, the experience of elderly persons is representative of overall trends in states such as California, Nevada, Florida, and Arizona (see Table 5).

\section{Policy Implications}

In summary, this paper, while recognizing the importance of net migration as a determinant of population change, has focused on changes in the components of net migration. These findings are of potential importance in the development of national population redistribution guidelines in a variety of ways. The perceived need for these guidelines, as well as the large amount of difference between ideal and actual residential patterns suggest that the present pattern of population distribution is, in some sense, suboptimum. Policies designed to alter the present pattern could achieve this aim by increasing or decreasing in (out) migration. Thus, for a given area there might be one or more conceivable goals: increase inmigration, decrease out migration, increase out migration, decrease inmigration. The data presented here indicate the relative efficacy of such alternatives. Suppose, for example, that a policy decision were made to redistribute population to North Dakota. This could be done by increasing inmigration, decreasing out migration, or by some combination'of the two. Table 1 shows that while the rate of inmigration to North Dakota increased by a relatively large amount between 1955-60 and 1965-70, the rate of out migration increased at twice this level in absolute terms. Hence, as shown in Table 2, the rate of net out migration increased. In this state, and in others with similar demographic experiences, appropriate policy instruments would be those aimed at curbing out migration. Given the evidence that much of out migration is economically motivated, appropriate instruments would be those creating employment opportunities.

This paper has also dealt with the issue of differential migration in terms of age and race. It would seem that the national guidelines called for by the Commission on Population Growth and the American future would attempt, to some degree, to cope with the problems associated with the so-called "flight to the suburbs," by whites and the increasing share of nonwhites in many of the nation's larger cities, particularly in the Northeast. The data in Table 3 shows the degree of which migration patterns to states, as a function of race, changed over the 1955-60 to 1965-70 period. One of the long standing patterns of population redistribution in the United States has been the movement of blacks from rural areas of the South to urban areas in the Northeast and Midwest. Although most Southern states continued to have a net loss of blacks through migration, the data show that in much of the Atlantic coastal portion of the South the rate of net out migration diminished over the period. Further south, however, the rate of net out migration among nonwhites increased. Consequently, policies designed to curb the flow of blacks out of the South would seem to be more useful in states such as Alabama, Mississippi, Louisiana or Arkansas, rather than Virginia, the Carolinas, or Georgia.

Age has long been regarded as an important determinant of migration. Much of the attention in this paper pertaining to the variable has dealt with military 
Table 5. Net Migration Rates for Persons aged 65 and over (1955-60 and 1965-70), and Rates of Return Migration, States

\begin{tabular}{|c|c|c|c|c|c|c|}
\hline State & $\begin{array}{c}\text { MNR, } 65+ \\
1955-60\end{array}$ & $\begin{array}{c}\text { MNR, 65+ } \\
1965-70\end{array}$ & $\begin{array}{c}\text { RMR, 5+ } \\
1965-70\end{array}$ & $\begin{array}{c}\text { RMR, 65+ } \\
1965-70\end{array}$ & $\begin{array}{l}\text { Ret. mig., } 5+ \\
\text { as a } \% \text { of total } \\
\text { inmig., } 5+\end{array}$ & $\begin{array}{c}\text { Ret. mig., } 65+ \\
\text { as a \% of total } \\
\text { inmig., } 65+\end{array}$ \\
\hline Maine & 0.4 & -0.1 & 5.5 & 3.3 & 27.2 & 45.6 \\
\hline New Hampshire & 0.4 & 1.9 & 5.8 & 3.1 & 12.4 & 20.3 \\
\hline Vermont & -0.7 & 0.3 & 5.4 & 2.4 & 19.8 & 36.3 \\
\hline Massachusetts & -1.9 & -1.9 & 6.0 & 2.2 & 21.6 & 39.6 \\
\hline Rhode Island & -1.9 & -1.1 & 5.4 & 2.2 & 15.8 & 34.5 \\
\hline Connecticut & -1.1 & -1.1 & 6.2 & 2.3 & 12.1 & 17.6 \\
\hline New York & -3.2 & -4.7 & 5.5 & 1.8 & 29.6 & 45.5 \\
\hline New Jersey & -0.5 & -0.5 & 7.1 & 3.6 & 14.3 & 19.6 \\
\hline Pennsylvania & -2.0 & -1.4 & 5.4 & 2.4 & 34.9 & 54.0 \\
\hline Ohio & -2.1 & -1.6 & 7.1 & 2.9 & 23.4 & 35.3 \\
\hline Indiana & -1.5 & -1.4 & 6.1 & 2.3 & 21.5 & 35.8 \\
\hline Illinois & -3.5 & -3.9 & 5.4 & 2.0 & 20.9 & 42.3 \\
\hline Michigan & -2.5 & -3.2 & 7.9 & 2.5 & 22.3 & 26.8 \\
\hline Wisconsin & -0.7 & -0.4 & 5.7 & 2.2 & 24.3 & 40.9 \\
\hline Minnesota & -1.4 & -1.7 & 5.8 & 1.8 & 25.3 & 41.0 \\
\hline Iowa & -1.9 & -0.9 & 3.9 & 1.3 & 28.7 & 46.3 \\
\hline Missouri & -1.1 & -0.3 & 5.3 & 2.2 & 23.8 & 42.0 \\
\hline North Dakota & -4.1 & -3.0 & 2.5 & 1.1 & 22.7 & 31.9 \\
\hline South Dakota & -2.4 & -1.6 & 2.7 & 1.1 & 23.1 & 33.7 \\
\hline Nebraska & -2.2 & -1.0 & 3.2 & 1.2 & 20.8 & 41.4 \\
\hline Kansas & -1.2 & -0.8 & 4.0 & 1.5 & 18.8 & 36.9 \\
\hline Delaware & 0.9 & 1.0 & 6.1 & 2.7 & 9.8 & 15.9 \\
\hline Maryland & 1.7 & 1.8 & 8.5 & 4.3 & 11.0 & 18.8 \\
\hline D. of $\mathrm{C}$. & -11.0 & -17.1 & 2.1 & 1.3 & 12.6 & 12.5 \\
\hline Virginia & 0.8 & 0.4 & 5.9 & 3.1 & 12.7 & 31.9 \\
\hline West Virginia & -2.6 & -1.7 & 4.4 & 2.7 & 44.3 & 52.6 \\
\hline North Carolina & 0.1 & 0.6 & 6.6 & 2.8 & 22.9 & 34.9 \\
\hline South Carolina & 0.0 & 0.8 & 5.1 & 1.9 & 20.3 & 36.3 \\
\hline Georgia & 0.0 & 0.2 & 6.1 & 2.1 & 19.3 & 36.7 \\
\hline Florida & 23.7 & 17.0 & 10.3 & 16.3 & 6.4 & 3.1 \\
\hline
\end{tabular}


Table 5. Net Migration Rates for Persons aged 65 and over (1955-60 and 1965-70), and Rates of Return Migration, States

\begin{tabular}{|c|c|c|c|c|c|c|}
\hline State & $\begin{array}{c}\text { MNR, } 65+ \\
1055-60\end{array}$ & $\begin{array}{c}\text { MNR, } 65+ \\
1965-70\end{array}$ & $\begin{array}{c}\text { RMR, 5+ } \\
1965-70\end{array}$ & $\begin{array}{c}\text { RMR, } 65+ \\
1965-70\end{array}$ & $\begin{array}{l}\text { Ret. mig., } 5+ \\
\text { as a \% of totai } \\
\text { inmig., } 5+\end{array}$ & $\begin{array}{c}\text { Ret. mig., } 65+ \\
\text { as a \% of total } \\
\text { inmig., } 65+\end{array}$ \\
\hline Kentucky & -0.8 & -0.6 & 4.8 & 2.2 & 33.0 & 59.5 \\
\hline Tennessea & 0.0 & 0.5 & 6.5 & 2.7 & 27.8 & 40.2 \\
\hline Alabama & -0.2 & 0.2 & 5.2 & 2.4 & 32.0 & 50.0 \\
\hline Mississippi & -0.8 & -0.5 & 4.0 & 1.9 & 31.6 & 52.6 \\
\hline Arkansas & 0.2 & 1.3 & 4.4 & 2.3 & 32.2 & 35.6 \\
\hline Louisiana & 0.4 & 0.1 & 6.0 & 2.2 & 23.5 & 33.0 \\
\hline Oklahoma & -0.2 & 0.8 & 5.2 & 2.3 & 26.3 & 22.7 \\
\hline Texas & 0.5 & 0.9 & 8.8 & 3.4 & 21.3 & 27.9 \\
\hline Montana & -2.7 & -1.8 & 3.8 & 2.9 & 17.4 & 15.9 \\
\hline Idaho & -1.1 & 0.3 & 5.0 & 1.6 & 17.7 & 11.0 \\
\hline Wyoming & -3.4 & -2.2 & 3.3 & 1.3 & 11.9 & 9.9 \\
\hline Colorado & 0.9 & 1.2 & 5.4 & 1.4 & 9.5 & 8.2 \\
\hline New Mexico & 1.5 & 1.7 & 4.3 & 1.8 & 12.1 & 6.5 \\
\hline Arizona & 17.0 & 13.2 & 6.0 & 4.4 & 5.7 & 2.0 \\
\hline Utah & -0.4 & -0.2 & 7.3 & 3.0 & 22.6 & 36.2 \\
\hline Nevada & 4.7 & "̋.1 & 4.3 & 1.5 & 3.2 & 1.8 \\
\hline Washington & 0.2 & 0.6 & 9.4 & 3.3 & 14.1 & 10.6 \\
\hline Oregon & 0.4 & 2.5 & 7.8 & 3.6 & 13.3 & 8.7 \\
\hline California & 4.1 & 1.8 & 11.7 & 9.5 & 10.0 & 4.8 \\
\hline Alaska & -16.5 & -23.0 & 4.4 & 0.0 & 3.1 & 0.0 \\
\hline Hawaii & 0.0 & (). 0 & 6.4 & 3.1 & 8.6 & 9.7 \\
\hline
\end{tabular}

Source: 1960 Census, Mobility for States and Economic Areas, Table 24

1970 Census, Mobility for States and the Nation, Table 59

State of Birth, Table 29

Lifetime and Recent Migration, Table 11 
migration, which is, after all, primarily a phenomenon of the young. This also, of course, is perhaps the most clear cut exarnple of an unintended demographic consequence of a federal government policy. As shown in Table 4, the importance of military migration can be very large-nearly thirty percent of the increased net migration to South Atlantic states was the result of military movements. Indeed, it might be argued that a population distribution policy of considerable import would be achieved merely by the relocation of federal employees. The case of the military serves as but one example of how effective such a policy could be.

Migration of the elderly is likely to become an increasingly larger portion of the nation's migration stream in the future, due to the prospective aging of the population. The usual sort of policy tools might not be as effective in dealing with this segment of the population, since migration is likely to be the primary consequence of employment considerations. One aspect which is not treated here, but worthy of further work, is the determinants and consequences of return migration among these persons. Some work has been done by Campbell etal. and by Long and Hansen, but there is considerable room for further treatment, particularly in terms of personal motivations. On the whole, it may be that redistribution of older persons is a phenomenon that can be more effectively dealt with at the state and local level (by land use and taxation policies, for example) than at the federal.

\title{
FOOTNOTES
}

\begin{abstract}
1Inmigration is the number of persons aged five and over residing in state at the time of the census, who were living in another state five years previously. Outmigration is the number who were living in the state five years previous, but who had moved out by the census date. Net migration is the difference between the two, while gross migration is their sum. In all cases, rates are computed by dividing the appropriate migration meaure by the number of persons (as of the census date) aged five and over, who reported a state of residence five years previous.

2Migration Efficiency is the ratio of net to gross migration. See [14, p. 285-294].

3It was necessary to compute nonwhite data for 1970, since the printed reports gave only "Total," "White," and "Negro." This was accomplished simply by subtracting "White" from "Total."

4Data from the 1970 Census of Population [18] show two kinds of military movement: that of persons in the military at the end of the period (tabulated by their place of residence at the beginning and end of the period) and that of persons in the military at the beginning of the period (again, tabulated by residence at both points in time). Unfortunately, the data do not permit separate tabulaions of persons in the military at both the beginning and ending points. Thus, an individual could be in either or both groups, depending on whether he or she was in the armed forces only in 1965, only in 1970, or in both 1965 and 1970. (Such data are available only for persons under age 30 in 1970.) In order to avoid double counting, then, the analysis here will concern only those persons in military service in 1970. Similar data are available for college students.
\end{abstract}

5This does not include movement of dependents.

6That is, either an increase in net migration or a decrease in net outmigration.

\section{REFERENCES}

1. Barsby, S. L. and D. R. Cox. Interstate Migration of the Elderly. Lexington: Lexington Books, 1975.

2. Blanco, C. "The Determinants of Interstate Population Movements," Journal of Regional Science, 5 (1963), 77-84.

3. Campbell, R. R., D. M. Johnson, and G. J. Stangler. "Return Migration of Black People to the South," Rural Sociology, 39 (1974), 514-528.

4. "Counterstream Migration of Black People to the South: Data from the 1970 Public Use Sample," Review of Public Data Use, 3 (1975), 13-21.

5. Commission on Population Growth and the American Future. Population and the American Future. Washington: U.S. Government Printing Office, 1972. 
6. Fuguitt, G. V. and J. J. Zuiches. "Residential Preferences and Population Distribution," Demography, 12 (1975), 491-509.

7. Greenwood, M. J. "Research on Internal Migration in the United States: A Survey," Journal of Economic Literature, 13 (1975), 397-433.

8. Heltman, L. R. "Mobility of the Aged in the United States," paper presented at the annual meeting of the Population Association of America, Seattle, 1975.

9. Lee, E. S. "A Theory of Migration," Demography, 3 (1966), 47-57.

10. Long, L. H. and K. A. Hansen. "Trends in Return Migration to the South," Demography, 12 (1975), forthcoming.

11. Lowry, I. S. Migration and Metropolitan Growth: Two Analytical Models. Los Angeles: University of California, Institute of Government and Public Affairs, 1966.

12. Morrison, P. A., "Guiding Urban Growth: Policy Issues and Demographic Constraints," paper presented at th eannual meeting of the Population Association of America, New York, 1974.

13. Renshaw, V., "Using Gross Migration Data from the Social Security Sample File," Demography, 11 (1974), 143-148.

14. Shryock, H. S. Population Mobility Within the United States. Chicago: University of Chicago, Community and Family Study Center, 1964.

15. Spengler, J. J. Declining Population Growth Revisited. Chapel Hills University of North Carolina, Carolina Population Center, 1971.

16. Sjaastad, L. A. "The Costs and Returns of Human Migration," Journal of Political Economy, 70 (1962), 80-93 (supplement).

17. U.S. Department of Commerce, Bureau of the Census. Lifetime and Recent Migration (1960 and 1970 Census). Washington: U.S. Government Printing Office, 1963 and 1973.

18. Mobility for States and the Nation (1970 Census). Washington: U.S. Government Printing Office, 1973.

19. Mobility for States and State Economic Areas (1960 Census). Washington: U.S. Government Printing Office, 1963.

20. State of Birth (1960 and 1970 Census). Washington: U.S. Government Printing Office, 1963 and 1973. 